\title{
Research on Spiritual Belief of Medical College Students
}

\author{
Wen $\mathrm{Hu}^{1, *}$, Hui Wang ${ }^{1}$ \\ ${ }^{1}$ Department of Psychology, Gannan Medical University, Ganzhou, Jiangxi 341000, China \\ *Corresponding author. Email: 84217248@qq.com
}

\begin{abstract}
In this paper, a questionnaire survey was conducted among 707 medical college students, and the following characteristics were found in different grades and majors. In terms of the general state of college students' spiritual belief, their social belief is the strongest, followed by pragmatistic belief, and their supernatural belief is the weakest; their social belief decreases with the increase of grade, but there is no significant difference between sophomores and juniors; the pragmatistic belief increases with the increase of grade, and the juniors and their seniors score the highest in pragmatistic belief; there are significant differences in supernatural beliefs among the three grades, but no significant differences between any two of them.
\end{abstract}

Keywords: college students, spiritual belief, social belief

\section{INTRODUCTION}

With the continuous development of modern education mechanism and market economy system, the opportunities and challenges faced by college students are also increasing [1]. College students are in the critical period of integrating into the society and forming their beliefs, during which they will also face many psychological problems. Research results show that college students' spiritual belief has a certain predictive effect on the development of individual psychology [3]. In combination with General Secretary Xi Jinping's belief view, belief plays an indispensable role in individuals, nations, countries and political parties [4]. Therefore, based on the spiritual belief of contemporary college students and its influencing factors, this study is carried out in order to provide useful reference for college students to establish a correct belief view and improve the quality of life.

\section{OBJECT AND METHODS}

\section{A. Object}

The students of all grades from an undergraduate medical school are selected as respondents. In the survey, 751 questionnaires were issued and 707 effective questionnaires were returned, with an effective rate of $94.14 \%$ and a high effective recovery rate. The sample distribution of subjects is shown in "Table I":

TABLE I. THE COMPOSITION OF THE EFFECTIVE SUBJECTS (N=707)

\begin{tabular}{|c|l|l|l|}
\hline demographic variables & \multicolumn{1}{|c|}{ level } & Pumber of people & Percentage (\%) \\
\hline gender & Male & 273 & 38.6 \\
\hline grade & Female & 434 & 61.4 \\
\hline & junior year and above & 133 & 18.8 \\
\hline & sophomore year & 162 & 22.9 \\
\hline major & freshman year & 412 & 58.3 \\
\hline & medico & 537 & 76.0 \\
\hline origin of student & non-medico & 170 & 24.0 \\
\hline & cities and towns & 241 & 34.1 \\
\hline & rural area & 466 & 65.9 \\
\hline
\end{tabular}

\section{B. Tools - questionnaire of college students' spiritual} belief [5]

The questionnaire was compiled by Song Xingchuan et al., with a total of 39 questions, and consists of three parts: supernatural belief, social belief

*Fund: Social Science Research Project of Ganzhou City in 2019 (Project No.: 19208). and pragmatistic belief. Supernatural belief includes religious belief and worship of gods, while social belief includes nationalism, statism and political belief. Pragmatistic belief includes life worship, money worship, family worship and familism. In this questionnaire, there are 5 levels of score, among which A 1 is a strong disagreement, and a 5 is a strong agreement. The higher the score is, the stronger the 
pursuit of the belief it shows. The coefficient of internal consistency of this part of questionnaire is 0.809 , indicating that the internal consistency of the 39 questions in the questionnaire is good.

\section{Statistic analysis}

The questionnaire is administered by group test. The experimenters are undergraduates majoring in psychology. The test has a uniform guideline. SPSS25.0 software was used to establish the database and conduct statistical analysis.

\section{RESULT}

\section{A. The general situation of college students' spiritual} belief

The repeated measurement method was used to test the overall difference and compare the three factors of spiritual belief. The results are shown in "Table II" and "Table III":

TABLE II. THE FACTOR DIFFERENCE TEST OF COLLEGE STUDENTS' BELIEFS

\begin{tabular}{|c|c|c|c|c|c|}
\hline & quadratic sum & $\begin{array}{l}\text { degree of } \\
\text { freedom }\end{array}$ & mean square & $\mathbf{F}$ & significance \\
\hline factor & 1651662.778 & 1 & 1651662.778 & 45854.063 & .000 \\
\hline error & 25430.111 & 706 & 36.020 & & \\
\hline
\end{tabular}

The "Table II" shows that $\mathrm{F}=45854.063, \mathrm{P}=0.000$, indicating that there is a significant difference between college students' supernatural belief, social belief and pragmatistic belief on the whole.

TABLE III. MULTIPLE COMPARISONS OF FACTORS IN COLLEGE STUDENTS' BELIEFS

\begin{tabular}{cllll}
\hline & mean value & standard error & Multiple comparison result \\
\hline $\boldsymbol{1}$ & 25.355 & 0.354 & $1<2 * * *$ & $1<3 * * *$ \\
\hline $\mathbf{2}$ & 62.901 & 0.343 & $2>1 * * *$ & $2>3 * * *$ \\
\hline $\mathbf{3}$ & 56.745 & 0.373 & $3>1 * * *$ & $3<2 * * *$ \\
\hline & & & a. Supernatural belief; 2, social belief; 3, pragmatistic belief
\end{tabular}

a. Supernatural belief: 2 , social belief; 3 , pragmatistic belief.

The "Table III" shows that there is a significant difference in college students' score of each belief ( $p<$ 0.001). The order of mean value of the three kinds of beliefs is social belief, pragmatistic belief and supernatural belief. This suggests that college students pay more attention to social beliefs, while supernatural beliefs take a secondary place.

B. Analysis on the influence of gender factors on college students' spiritual belief

TABLE IV. COMPARISON OF SPIRITUAL BELIEF SCORES OF COLLEGE STUDENTS OF DIFFERENT GENDERS

\begin{tabular}{|c|c|c|c|c|c|}
\hline & gender & $\begin{array}{c}\text { number of } \\
\text { cases }\end{array}$ & mean value & $\begin{array}{l}\text { standard } \\
\text { deviation }\end{array}$ & $\mathbf{t}$ \\
\hline \multirow{2}{*}{$\begin{array}{c}\text { Total score of supernatural } \\
\text { belief }\end{array}$} & male & 273 & 24.685 & 9.57 & \multirow[t]{2}{*}{-1.502} \\
\hline & female & 434 & 25.776 & 9.30 & \\
\hline \multirow[t]{2}{*}{ total score of social belief } & male & 273 & 62.454 & 10.46 & \multirow[t]{2}{*}{-0.977} \\
\hline & female & 434 & 63.182 & 8.16 & \\
\hline \multirow{2}{*}{$\begin{array}{c}\text { total score of pragmatistic } \\
\text { belief }\end{array}$} & male & 273 & 57.223 & 10.57 & \multirow[t]{2}{*}{1.016} \\
\hline & female & 434 & 56.444 & 9.47 & \\
\hline \multirow{2}{*}{$\begin{array}{c}\text { Total score of spiritual } \\
\text { belief }\end{array}$} & male & 273 & 144.36 & 19.605 & \multirow[t]{2}{*}{-0.748} \\
\hline & female & 434 & 145.40 & 16.93 & \\
\hline
\end{tabular}

The "Table IV" shows that there is no significant difference in the total score of spiritual belief and each dimension in different gender. That is, there is no significant difference between male and female students in spiritual beliefs.

\section{Characteristics of spiritual belief development of college students of different grades}

The overall spiritual beliefs and scores of each dimension of students in different grades were compared and the results show that the scores of students in different grades differ significantly in the overall spiritual belief and its dimensions; in the dimension of supernatural belief, the score of freshmen $<$ score of juniors and above < score of sophomores; in 
the dimension of pragmatistic belief, score of freshmen $<$ score of sophomores < score of juniors or above; in the dimension of social belief, > score of freshmen > score of sophomores $>$ score of juniors or above; and in terms of the overall score of spiritual belief, score of freshmen $<$ score of sophomores < score of juniors or above.

TABLE V. COMPARISON OF SPIRITUAL BELIEF SCORES OF COLLEGE STUDENTS OF DIFFERENT GRADES (N=70)

\begin{tabular}{ccccc}
\hline item & freshman year & sophomore year & $\begin{array}{c}\text { junior year and } \\
\text { above }\end{array}$ & F \\
\hline $\begin{array}{c}\text { supernatural } \\
\text { belief }\end{array}$ & $24.59 \pm 9.31$ & $26.10 \pm 9.63$ & $25.81 \pm 9.32$ & $3.454^{* * *}$ \\
pragmatistic belief & $54.93 \pm 9.78$ & $57.64 \pm 9.58$ & $61.27 \pm 9.19$ & $22.676^{* * *}$ \\
social belief & $64.16 \pm 8.44$ & $61.67 \pm 9.57$ & $60.48 \pm 9.93$ & $10.372^{* * *}$ \\
$\begin{array}{c}\text { total score of } \\
\text { spiritual belief }\end{array}$ & $143.70 \pm 17.36$ & $145.40 \pm 18.27$ & $148.56 \pm 19.24$ & $3.758^{* * *}$ \\
\hline
\end{tabular}

From "Table V", it can be seen that the F value of the anova overall test is significant on the total score of supernatural belief, pragmatistic belief, social belief and spiritual belief. Furthermore, the Scheffe method was used to make posterior comparisons, and the result is shown in "Table VI".

TABLE VI. MULTIPLE COMPARISONS OF SPIRITUAL BELIEFS AMONG COLLEGE STUDENTS OF DIFFERENT GRADES

\begin{tabular}{|c|c|c|c|c|c|c|c|}
\hline \multirow{2}{*}{$\begin{array}{l}\text { dependent } \\
\text { variable }\end{array}$} & \multirow[t]{2}{*}{ grade } & \multirow[t]{2}{*}{ grade } & \multirow{2}{*}{$\begin{array}{c}\text { Mean } \\
\text { difference (I- } \\
\mathbf{J})\end{array}$} & \multirow{2}{*}{$\begin{array}{l}\text { standard } \\
\text { error }\end{array}$} & \multirow[t]{2}{*}{ significance } & \multicolumn{2}{|c|}{ confidence interval of $95 \%$} \\
\hline & & & & & & lower limit & upper limit \\
\hline \multirow{3}{*}{$\begin{array}{c}\text { total score of } \\
\text { supernatural } \\
\text { belief }\end{array}$} & $\begin{array}{l}\text { freshma } \\
\text { n year }\end{array}$ & sophomore year & -1.49793 & 0.87044 & 0.228 & -3.6331 & 0.6372 \\
\hline & & $\begin{array}{l}\text { junior year and } \\
\text { above }\end{array}$ & -2.21737 & 0.93608 & 0.061 & -4.5135 & 0.0788 \\
\hline & $\begin{array}{l}\text { sophom } \\
\text { ore year }\end{array}$ & $\begin{array}{l}\text { junior year and } \\
\text { above }\end{array}$ & -0.71944 & 1.09829 & 0.807 & -3.4135 & 1.9746 \\
\hline \multirow[t]{3}{*}{$\begin{array}{l}\text { total score of } \\
\text { social belief }\end{array}$} & $\begin{array}{l}\text { freshma } \\
\mathrm{n} \text { year }\end{array}$ & sophomore year & $2.49221 *$ & 0.83492 & 0.012 & 0.4442 & 4.5402 \\
\hline & & junior and above & $3.68385^{*}$ & 0.89788 & 0.000 & 1.4814 & 5.8863 \\
\hline & $\begin{array}{l}\text { sophom } \\
\text { ore year }\end{array}$ & $\begin{array}{l}\text { junior year and } \\
\text { above }\end{array}$ & 1.19164 & 1.05347 & 0.528 & -1.3925 & 3.7758 \\
\hline \multirow{3}{*}{$\begin{array}{c}\text { total score of } \\
\text { pragmatistic } \\
\text { belief }\end{array}$} & $\begin{array}{l}\text { freshma } \\
\text { n year }\end{array}$ & sophomore year & $-2.70134 *$ & 0.89276 & 0.011 & -4.8913 & -0.5114 \\
\hline & & $\begin{array}{l}\text { junior year and } \\
\text { above }\end{array}$ & $-6.33621 *$ & 0.96099 & 0.000 & -8.6913 & -3.9811 \\
\hline & $\begin{array}{l}\text { sophom } \\
\text { ore year }\end{array}$ & $\begin{array}{l}\text { junior year and } \\
\text { above }\end{array}$ & $<$ br $>$ & 1.12646 & 0.006 & -6.3980 & -0.8717 \\
\hline \multirow{3}{*}{$\begin{array}{c}\text { total score of } \\
\text { spiritual } \\
\text { belief }\end{array}$} & $\begin{array}{l}\text { freshma } \\
\text { n year }\end{array}$ & sophomore year & -1.70706 & 1.66323 & 0.591 & -5.7869 & 2.3728 \\
\hline & & $\begin{array}{l}\text { junior year and } \\
\text { above }\end{array}$ & $-4.86974 *$ & 1.78866 & 0.025 & -9.2572 & -0.4822 \\
\hline & $\begin{array}{l}\text { sophom } \\
\text { ore year }\end{array}$ & $\begin{array}{l}\text { junior year and } \\
\text { above }\end{array}$ & -3.16268 & 2.09860 & 0.322 & -8.3105 & 1.9851 \\
\hline
\end{tabular}

It can be seen from "Table VI" that, freshmen score significantly lower than those of juniors and above in terms of the pragmatistic belief and overall spiritual belief and significantly higher in terms of the total social belief score than that of juniors and above, with no significant difference in supernatural belief between them. They score significantly higher than that of sophomores in term of social belief, and significantly lower in terms of the pragmatistic belief than sophomores. Sophomores score significantly lower in 
terms of pragmatistic belief than juniors and their seniors, and there was no significant difference in other beliefs and overall spiritual beliefs between them.

\section{DISCUSSION}

\section{A. The spiritual belief of contemporary college students is dominated by social belief}

The results of this study show that among the three spiritual beliefs of college students, social belief scores the highest, followed by pragmatistic belief and supernatural belief scores the lowest, which is consistent with the previous research results [7] [8]. China's valuable cultural wealth of five thousand years has had a profound impact on the contemporary Chinese people. Social belief attaches great importance to the unity of loving family, country and society, which is inseparable from the fine traditional culture of the Chinese nation. With the thoughts of "patriotic loyalty" and "serve the country worthily" in traditional Chinese culture deeply imprinted in the minds of all Chinese people, in the context of the new era, the belief of the nation, the belief of the great Communist Party of China, is the main belief of contemporary college students [9]. However, contemporary college students have been receiving education of science, Marxism and "atheism" since they are young, so they are less influenced by Buddhism, Christianity and other religions [3], thus score the lowest in supernatural belief.

\section{B. College students of different grades have significant differences in the three dimensions of spiritual belief}

In terms of supernatural beliefs, sophomores score highest and freshmen lowest. Song Chuanxing shows that there are differences in supernatural beliefs among college students of different grades. There are significant differences between religious belief and god worship, especially in the third year [7]. However, in this study, grade difference is not obvious, which is inconsistent with the existing research and needs further discussion.

In terms of social belief, freshmen score significantly higher than sophomores, juniors and above, with the belief decreasing as the grade increases, which is consistent with existing studies [7]. This may be related to the compulsory course "Basic Principle of Marxism" provided by the university in the freshman year. Through this course, students have accepted many materialist thought and increased their Socialist belief.

The pragmatistic belief of college students tend to increase with the growth of grade. Juniors and their seniors score significantly higher than sophomores, and sophomores score significantly higher than freshmen. This is because college students have a deeper understanding of material social life with the increased age and social experience. Li Yousui's research points out that with the increase of age, the pursuit of material belief becomes stronger and stronger [10]. With the enrichment of social experience, contemporary college students have a deeper understanding of social life and increasingly understand the importance of practical skills to individual life.

\section{CONCLUSION}

This paper comes to the following conclusions:

First, on the whole situation of college students spiritual belief, social belief accounts for the most proportion, pragmatistic belief next and supernatural belief the least.

Second, some spiritual beliefs of college students are different in grade. Social belief decreases with the increase of grade, but there is no significant difference between sophomore year and junior year and above; the pragmatistic belief increases with the increase of grade and the juniors and above score the highest in terms of pragmatistic belief.

Third, there are significant differences in supernatural beliefs among the three grades, yet none between any of the two.

\section{References}

[1] Song Xingchuan, Jin Shenghua. Correlations Between Beliefs and Mental Health [J]. Chinese Mental Health Journal, 2004, 18 (8): 554-556. (in Chinese)

[2] Block J, Kremen AM. IQ and ego resiliency: conceptual and empirical connections and separateness [J]. J Pers Soc Psychol, 1996, 70(2): 349-361.

[3] Han Li, Liao Chuanjing, Zheng Yong. Status of spiritual belief and psychological resilience and their correlations among university students [J].

[4] Chin J Public Health, Mar 2014 Vol. 30 No. 3.: 275-278. (in Chinese)

[5] Fei Longfei, Zhang Hui, Ma Ying. An analysis of Xi Jinping's Thoughts on Beliefs [J]. Comparative Study of Cultura Innovation. 2019 (33): 18-19. (in Chinese)

[6] Song Xingchuan. A Research on the Present Situation of Spiritual Belief of University Students [D]. Beijing: doctoral dissertation, Beijing Normal University, 2003

[7] Kathryn M. Connor, Jonathan R. T. Davidson. (2003) Development of A New Resilience Scale: The ConnorDavidson Resilience Scale (CD-RISC). Depression and Anxiety, 18: 76-82.

[8] Song Xingchuan, Jin Shenghua. A Study on Beliefs of University Students' from Different Grades and from Different Major [J]. Psychological Development and Education. 2006(01): 92-96. (in Chinese)

[9] Zhang Kai, Wu Shoubao, Zhao Jinyan. Status of College Students' Spiritual Belief and Its Relationship with Subjective Well-being [J]. Journal of Huaibei Normal University (Philosophy and Social Sciences), 2010, 31 (01): 145-148. (in Chinese) 
[10] Song Xingchuan, Jin Shenghua. A Research on the Present Situation of Spiritual Belief of University Students [J]. Journal of Psychological Science, 2004 (04): 1010-1012. (in Chinese)

[11] Li Yousui, Li Wei, Lv Yong. Psychological Research on the Status Quo of Belief. Psychological Science, 2002, 25 (6): 660663. (in Chinese)

[12] Zhang Yunhong, Pan Ling, Zhang Hongpo. The Role of Mental Resilience in thePrevention of Psychological Crisis in College Students [J]. China Journal of Health Psychology, 2016, 24 (06): 903-906. (in Chinese) 